Www.jmscr.igmpublication.org
Impact Factor 3.79

ISSN (e)-2347-176x

crossref DOI: _http://dx.doi.org/10.18535/jmscr/v3i8.68
Journal Of Medical Science And Clinical Research

IGM Publication

An official Publication of IGM Publication

\title{
Comparative Evaluation of Classical Subarachnoid Block, Unilateral Subarachnoid Block and Low Dose Subarachnoid Block with Fentanyl in ASA III and ASA IV Patients Undergoing Lower Limb Surgeries
}

Authors

\author{
Dr Alladi Srikanth ${ }^{1}$, Dr Pradeep Samuel Indurkar ${ }^{2}$, Dr Manda H, Nagrale ${ }^{3}$ \\ ${ }^{1}$ Assistant Professor, Dept of Anesthesia, Mamata Medical College, Khammam. Andhra Pradesh. India \\ $\mathrm{Ph}-9885202463$ \\ ${ }^{2}$ Associate Professor, Dept of Anesthesia, Mamata Medical College, Khammam Andhra Pradesh. India \\ $\mathrm{Ph}-9704267305$ \\ ${ }^{3}$ Professor and HOD, Dept of Anesthesia, Mamata Medical College, Khammam Andhra Pradesh India \\ Ph- 7719969901 \\ Corresponding Author \\ Dr Pradeep Samuel Indurkar \\ Associate Professor, Department of Anesthesia, Mamata Medical \\ College, Khammam Andhra Pradesh India Ph-9704267305
}

\begin{abstract}
Spinal anaesthesia is considered as a safe technique but can be detrimental to patients with hemodynamic instability. Safety improves if the block can be localized to the area of surgery. Patients with ASA3 and ASA4 grades are haemodynamically unstable. Hence an effective alternative may be unilateral subarachnoid block for lower extremity surgeries.
\end{abstract}

Aim-to compare classical subarachnoid block(SAB) with unilateral SAB and low dose SAB. Method-60 patients were divided in three groups. Control Group received $2 \mathrm{ml}$ of $0.5 \%$ Bupivacaine and turned to supine position immediately. STUDY Group I received $2 \mathrm{ml}$ of $0.5 \%$ Bupivacaine and kept in lateral position for 10 minutes and then turned supine. STUDY Group II received $1.5 \mathrm{ml}$ of $0.5 \%$ Bupivacaine with $25 \mu \mathrm{g}(0.5 \mathrm{ml})$ Fentanyl and kept in lateral position for 10 minutes and then turned supine. Sensory blockade, motor blockade and haemodynamic parameters were studied.

Results- Bradycardia and hypotension requiring treatment was less in both study groups. Unilateral spinal block and low dose spinal block induced lesser degree of motor blockade. There was no statistical difference in the onset time and duration of sensory and motor blockade among the 3 groups.

Conclusion- we conclude that in high risk patients undergoing unilateral lower limb surgeries Unilateral low dose subarachnoid block offers better hemodynamic stability during the intra-operative period without affecting the quality of sensory and motor blockade

Key words- Sabarachnoid block, unilateral block, low dose spinal, Bupivaicain.

\section{INTRODUCTION}

Spinal anaesthesia continues to be most common anaesthetic technique due to rapid onset, safety and simplicity. Even this relatively safe technique can have complications such as hypotension, which a normal patient can tolerate but can be 
detrimental $^{1}$ to patients with hemodynamic instability. The safety improves if the block can be localized $^{2}$ to the area of surgery. Hence an efficient alternative may be unilateral spinal anaesthesia ${ }^{3}$.

Even though performing spinal anaesthesia is technically easier, complications (like hypotension and bradycardia) can be detrimental to high risk group of patients. Unilateral spinal anaesthesia can be used frequently in lower limb surgery ${ }^{4,5}$ with less hemodynamic complications, ${ }^{6}$ selective block on operating side, avoidance of unnecessary paralysis on nonoperating side, better mobilization during recovery period, lower incidence of postoperative urine retention, ${ }^{7}$ as well as good patient satisfaction. ${ }^{8}$ Addition of Fentanyl to Bupivacaine is an established technique to reduce the dose of anaesthetic and to maintain heamodynamic stability ${ }^{5}$. However addition of Fentanyl can change baricity ${ }^{9,10}$ of the local anaesthetic and can alter the effect of intended unilateral spinal analgesia.

The present randomized double blind study was designed to see if addition of Fentanyl could reduce the dose of Bupivacaine and maintain the unilateral nature of anaesthesia. This study was done to compare the efficacy of classical subarachnoid block, unilateral subarachnoid block, low dose subarachnoid block with fentanyl in ASAIII and ASAIV patients undergoing lower limb surgeries.

\section{AIM}

To compare efficacy of classical subarachnoid block using $0.5 \%$ Bupivacaine $(2 \mathrm{ml})$, unilateral spinal anaesthesia using $0.5 \%$ Bupivacaine $(2 \mathrm{ml})$ and low dose spinal anaesthesia using $0.5 \%$ Bupivacaine $(1.5 \mathrm{ml})$ with Fentanyl $(0.5 \mathrm{ml} / 25$ micro grams) in high risk patients undergoing unilateral lower limb surgeries.

\section{OBJECTIVES}

1. Feasibility of maintaining unilaterality of subarachnoid block.
2. Haemodynamic stability in peri-operative period.

3. Onset, quality and duration of block

\section{MATERIALS AND METHODS}

This prospective comparative study was done on 60 patients (ASA status III and IV). Approval by the institution's research and ethics committee was obtained. The patients were divided into three groups of 20 each.

1. Control Group - Received $2 \mathrm{ml} \quad 0.5 \%$ Bupivacaine and turned to supine position immediately.

2. STUDY Group I - Received $2 \mathrm{ml} 0.5 \%$ Bupivacaine and kept in lateral decubitus position for 10 minutes and then turned supine.

3. STUDY Group II - Received $1.5 \mathrm{ml} 0.5$ $\%$ Bupivacaine with $25 \mu \mathrm{g}(0.5 \mathrm{ml})$ Fentanyl and kept in lateral decubitus position for 10 minutes and then turned supine.

\section{Inclusion criteria}

1. Patients between 18 to 80 years of age.

2. Patients belonging to ASA physical status III and IV

3. Undergoing emergency unilateral lower limb surgery.

\section{Exclusion criteria}

1. All contraindications for central neuraxial block.

2. Patients who are not co-operative to positioning for subarachnoid block.

3. Patients with anomalies of the spinal column

Patients were allocated into three groups by simple randomization using sealed envelope method.

\section{PRE-OPERATIVE PREPARATION}

Informed consent was obtained. I.V. line secured with wide bore cannula. Preloading with crystalloid solution was done. All base line vitals were recorded. 
Investigator was blinded to drug as the study solution was prepared by an anaesthesiologist who was not involved with administration of spinal anaesthesia and monitoring of patients. Using 23 gauge Quincke's needle spinal anaesthesia was given in lateral position (the side to be operated on as the dependent side) after assuring free flow of CSF. Patients were kept in lateral position for 10 minutes before positioning for surgery.

\section{RECORDING OF DATA}

Intraoperatively, heart rate, systolic and diastolic blood pressure was recorded every five minutes for 60 minutes and in recovery room and there after every 30 minutes till the time oral analgesic was given.

1. Sensory blockade was assessed in dependent as well as non-dependent limb using pin prick by a blinded observer. Sensory levels were checked every 5 minutes after positioning the patients for 60 minutes and in post operative period.

2. Motor blockade was assessed using modified BROMAGE score

Both the dependant as well as nondependent limbs were assessed for motor blockade at 15, 30 and 60 minutes after positioning the patient.

Duration of motor blockade and duration of analgesia were also noted.

3. Side effects such as nausea, vomiting and pruritis were recorded in introperative period.

\section{STATISTICAL METHOD}

All recorded data entered and analyzed using Microsoft excel for determining statistical significance. Comparison of the means between the groups was done by analysis of variance (ANOVA) and chi square test. A p-value $<0.05$ is considered significant.

\section{OBSERVATIONS AND RESULTS}

The demographic data revealed that all 3 groups are comparable in age, height, and sex ratios. There was no statistically significant difference between the groups with regard to demographic data.

Heart rate comparison revealed that the occurrence of bradycardia requiring treatment was more in control group (30\%) versus the study group I (15\%) and study group II (15\%).This difference was found to be statistically significant. (Table 1)

Hypotension -drop of Systolic blood pressure more than $30 \%$ of base line. Hypotension comparison revealed that occurrence of hypotension requiring treatment was more in control group (35\%) versus the study group I (20\%) and study group II (20\%).This difference was found to be statistically significant. (Table 2). (Table 3)

Motor blockade- Unilateral spinal block and low dose spinal block induced lesser degree of motor blockade when compared to the classical subarachnoid block group. This difference was found to be statistically significant(Table 4)

Table 1. Comparison of percentage of bradycardia among three groups

\begin{tabular}{|c|c|c|c|}
\hline Groups & Control group & Study group I & Study group II \\
\hline Total & 20 & 20 & 20 \\
\hline Bradycardia with treatment & 6 & 3 & 3 \\
\hline Percentage & 30 & 15 & 15 \\
\hline
\end{tabular}

$\mathrm{p}=0.02$ (statistically significant) 


\section{JMSCR Vol||3||Issue||9||Page 7697-7705||September}

Table 2. Comparison of percentage of hypotension among three groups

\begin{tabular}{|c|c|c|c|}
\hline Group & Control group & Study group I & Study group II \\
\hline Total & 20 & 20 & 20 \\
\hline $\begin{array}{c}\text { Hypotension with } \\
\text { treatment }\end{array}$ & 7 & 4 & 4 \\
\hline Percentage & 35 & 20 & 20 \\
\hline
\end{tabular}

$\mathrm{p}=0.013$ (statistically significant)

Table 3. Shows variations in haemodynamics among three groups

\begin{tabular}{|c|c|c|c|c|c|c|c|c|c|}
\hline & Preop & $\begin{array}{c}5 \\
\min \end{array}$ & $\begin{array}{c}10 \\
\min \end{array}$ & $\begin{array}{c}15 \\
\min \end{array}$ & $\begin{array}{c}20 \\
\min \end{array}$ & $\begin{array}{c}25 \\
\min \end{array}$ & $\begin{array}{c}30 \\
\min \end{array}$ & $\begin{array}{c}45 \\
\min \end{array}$ & $\begin{array}{c}60 \\
\min \end{array}$ \\
\hline \multicolumn{10}{|c|}{ Control group } \\
\hline $\begin{array}{l}\mathrm{H} \\
\mathrm{R}\end{array}$ & $\begin{array}{c}85.3 \pm 1 \\
0.57\end{array}$ & $\begin{array}{c}76.4 \pm 7 \\
.82\end{array}$ & $\begin{array}{c}68 \pm 11 \\
23\end{array}$ & $\begin{array}{c}74 \pm 12 . \\
25\end{array}$ & $\begin{array}{c}79.2 \pm 1 \\
2.21\end{array}$ & $\begin{array}{c}79.55 \pm \\
11.0\end{array}$ & $\begin{array}{l}80.95 \\
\pm 9.93\end{array}$ & $\begin{array}{c}80.85 \pm \\
8.48\end{array}$ & $\begin{array}{c}81.6 \pm 7 \\
.78\end{array}$ \\
\hline $\begin{array}{l}\mathrm{S} \\
\mathrm{B} \\
\mathrm{P}\end{array}$ & $\begin{array}{c}137.4 \pm \\
11.34\end{array}$ & $\begin{array}{r}125.15 \\
\pm 13.68\end{array}$ & $\begin{array}{l}115.55 \\
\pm 17.01\end{array}$ & $\begin{array}{l}114.05 \\
\pm 15.97\end{array}$ & $\begin{array}{c}114.1 \pm \\
13.78\end{array}$ & $\begin{array}{l}114.45 \\
\pm 12.58\end{array}$ & $\begin{array}{l}115.2 \\
\pm 11.2\end{array}$ & $\begin{array}{c}116.9 \pm \\
10.67\end{array}$ & $\begin{array}{l}116.55 \\
\pm 13.50\end{array}$ \\
\hline $\begin{array}{l}\mathrm{D} \\
\mathrm{B} \\
\mathrm{P} \\
\end{array}$ & $\begin{array}{c}87.2 \pm 1 \\
2.02\end{array}$ & $\begin{array}{c}77.75 \pm \\
11.89\end{array}$ & $\begin{array}{c}70.55 \pm \\
11.19\end{array}$ & $\begin{array}{c}68 \pm 10 \\
1\end{array}$ & $\begin{array}{c}67.45 \pm \\
8.85\end{array}$ & $\begin{array}{c}69.2 \pm 9 \\
.45\end{array}$ & $\begin{array}{c}68.9 \pm \\
9.43\end{array}$ & $\begin{array}{c}70.8 \pm 9 \\
.05\end{array}$ & $\begin{array}{c}72.6 \pm 1 \\
0.05\end{array}$ \\
\hline \multicolumn{10}{|c|}{ Study group I } \\
\hline $\begin{array}{l}\mathrm{H} \\
\mathrm{R}\end{array}$ & $\begin{array}{c}77.5 \pm 9 \\
.66 \\
\end{array}$ & $\begin{array}{c}74.8 \pm 9 \\
.62 \\
\end{array}$ & $\begin{array}{c}71.3 \pm 1 \\
2.20 \\
\end{array}$ & $\begin{array}{c}77.95 \pm \\
11.85 \\
\end{array}$ & $\begin{array}{c}77.3 \pm 1 \\
1.27 \\
\end{array}$ & $\begin{array}{c}77.6 \pm 1 \\
1.69 \\
\end{array}$ & $\begin{array}{r}76.85 \\
\pm 10.7 \\
\end{array}$ & $\begin{array}{c}76.45 \pm \\
10.44 \\
\end{array}$ & $\begin{array}{c}77.05 \pm \\
10.34 \\
\end{array}$ \\
\hline $\begin{array}{l}\mathrm{S} \\
\mathrm{B} \\
\mathrm{P}\end{array}$ & $\begin{array}{l}134.05 \\
\pm 10.79\end{array}$ & $\begin{array}{l}121.55 \\
\pm 12.56\end{array}$ & $\begin{array}{c}119.4 \pm \\
17.41\end{array}$ & $\begin{array}{c}120.3 \pm \\
16.01\end{array}$ & $\begin{array}{c}122.6 \pm \\
13.12\end{array}$ & $\begin{array}{l}122.45 \\
\pm 12.73\end{array}$ & $\begin{array}{l}121.9 \\
\pm 11.7\end{array}$ & $\begin{array}{l}122.65 \\
\pm 11.20\end{array}$ & $\begin{array}{l}122.25 \\
\pm 11.63\end{array}$ \\
\hline $\begin{array}{l}\mathrm{D} \\
\mathrm{B} \\
\mathrm{P}\end{array}$ & $\begin{array}{c}83.35 \pm \\
8.82\end{array}$ & $\begin{array}{c}71.2 \pm 1 \\
3.01\end{array}$ & $\begin{array}{c}71.35 \pm \\
11.62\end{array}$ & $\begin{array}{c}73.75 \pm \\
10.41\end{array}$ & $\begin{array}{c}75.25 \pm \\
9.64\end{array}$ & $\begin{array}{c}74.55 \pm \\
9.43\end{array}$ & $\begin{array}{l}74.65 \\
\pm 8.80\end{array}$ & $\begin{array}{c}76.25 \pm \\
9.10\end{array}$ & $\begin{array}{c}76.35 \pm \\
8.23\end{array}$ \\
\hline \multicolumn{10}{|c|}{ Study group II } \\
\hline $\begin{array}{l}\mathrm{H} \\
\mathrm{R}\end{array}$ & $\begin{array}{c}92.55 \pm \\
11.86 \\
\end{array}$ & $\begin{array}{c}87.3 \pm 1 \\
4.28 \\
\end{array}$ & $\begin{array}{c}83.25 \pm \\
17.32 \\
\end{array}$ & $\begin{array}{c}86.95 \pm \\
9.51 \\
\end{array}$ & $\begin{array}{c}86.45 \pm \\
9.27\end{array}$ & $\begin{array}{c}86.6 \pm 8 \\
.32 \\
\end{array}$ & $\begin{array}{c}87.4 \pm \\
7.83 \\
\end{array}$ & $\begin{array}{c}85.5 \pm 8 \\
.12 \\
\end{array}$ & $\begin{array}{c}85.8 \pm 8 \\
.76 \\
\end{array}$ \\
\hline $\begin{array}{l}\mathrm{S} \\
\mathrm{B} \\
\mathrm{P}\end{array}$ & $\begin{array}{l}135.95 \\
\pm 11.35\end{array}$ & $\begin{array}{c}130.1 \pm \\
13.83\end{array}$ & $\begin{array}{l}123.95 \\
\pm 17.73\end{array}$ & $\begin{array}{c}122.1 \pm \\
14.45\end{array}$ & $\begin{array}{l}120.35 \\
\pm 13.31\end{array}$ & $\begin{array}{l}118.85 \\
\pm 13.91\end{array}$ & $\begin{array}{l}118.9 \\
\pm 13.1\end{array}$ & $\begin{array}{l}118.25 \\
\pm 12.93\end{array}$ & $\begin{array}{r}120.25 \\
\pm 12.39\end{array}$ \\
\hline $\begin{array}{l}\mathrm{D} \\
\mathrm{B} \\
\mathrm{P}\end{array}$ & $\begin{array}{c}84.25 \pm \\
10.42\end{array}$ & $\begin{array}{c}80.2 \pm 1 \\
0.95\end{array}$ & $\begin{array}{c}75.3 \pm 1 \\
2.57\end{array}$ & $\begin{array}{c}74.35 \pm \\
11.39\end{array}$ & $\begin{array}{c}73.2 \pm 1 \\
0.69\end{array}$ & $\begin{array}{c}72.95 \pm \\
11.6\end{array}$ & $\begin{array}{l}72.65 \\
\pm 11.2\end{array}$ & $\begin{array}{c}72.4 \pm 1 \\
1.31\end{array}$ & $\begin{array}{c}73.15 \pm \\
11.17\end{array}$ \\
\hline
\end{tabular}


Table 4. Shows comparison of motor blockade in all three groups

\begin{tabular}{|c|c|c|c|c|c|c|c|c|c|c|}
\hline \multirow{5}{*}{ At } & \multirow{5}{*}{15} & \multicolumn{5}{|l|}{ Dependent } & \multicolumn{4}{|c|}{ Non dependent } \\
\hline & & $\begin{array}{c}\text { Bromage } \\
\text { scale }\end{array}$ & 0 & 1 & 2 & 3 & 0 & 1 & 2 & 3 \\
\hline & & $\begin{array}{c}\text { Control } \\
\text { groun }\end{array}$ & 0 & 0 & 3 & 17 & 0 & 0 & 3 & 17 \\
\hline & & $\begin{array}{l}\text { Study } \\
\text { group I }\end{array}$ & 2 & 0 & 7 & 11 & 8 & 2 & 4 & 6 \\
\hline & & $\begin{array}{l}\text { Study } \\
\text { group II }\end{array}$ & 1 & 0 & 7 & 12 & 6 & 7 & 2 & 5 \\
\hline \multirow{3}{*}{$\begin{array}{c}\text { At } \\
\text { minutes }\end{array}$} & \multirow{3}{*}{30} & $\begin{array}{l}\text { Control } \\
\text { group }\end{array}$ & 0 & 0 & 3 & 17 & 0 & 0 & 3 & 17 \\
\hline & & $\begin{array}{l}\text { Study } \\
\text { group I }\end{array}$ & 2 & 0 & 7 & 11 & 6 & 3 & 3 & 8 \\
\hline & & $\begin{array}{l}\text { Study } \\
\text { group II }\end{array}$ & 1 & 0 & 7 & 12 & 4 & 7 & 3 & 6 \\
\hline \multirow[t]{3}{*}{$\begin{array}{c}\text { At } \\
\text { minutes }\end{array}$} & \multirow[t]{3}{*}{60} & $\begin{array}{l}\text { Control } \\
\text { group }\end{array}$ & 0 & 0 & 0 & 20 & 0 & 0 & 0 & 20 \\
\hline & & $\begin{array}{l}\text { Study } \\
\text { group I }\end{array}$ & 0 & 0 & 8 & 12 & 6 & 2 & 4 & 8 \\
\hline & & $\begin{array}{l}\text { Study } \\
\text { group II }\end{array}$ & 0 & 0 & 8 & 12 & 4 & 5 & 3 & 8 \\
\hline
\end{tabular}

Table 5. Comparison of onset and duration of sensory and motor blockade among three groups

\begin{tabular}{|c|c|c|c|c|c|}
\hline & Control group & $\begin{array}{c}\text { Study group } \\
\text { I }\end{array}$ & $\begin{array}{c}\text { Study group } \\
\text { II }\end{array}$ & f-value & p value \\
\hline $\begin{array}{c}\text { Onset of } \\
\text { Sensory } \\
\text { Blockade(sec) }\end{array}$ & $109 \pm 21.6$ & $106 \pm 25.88$ & $108.5 \pm 23.2$ & 0.155 & 0.857 \\
\hline $\begin{array}{c}\text { Onset of } \\
\text { Motor } \\
\text { Blockade(sec) }\end{array}$ & $206.75 \pm 52.14$ & $204.5 \pm 40.29$ & $197.5 \pm 39.31$ & 0.237 & 0.790 \\
\hline $\begin{array}{c}\text { Duration of } \\
\text { Motor } \\
\text { Blockade(min) }\end{array}$ & $86.75 \pm 15.99$ & $90.5 \pm 10.8$ & $91 \pm 13.91$ & 0.570 & 0.569 \\
\hline $\begin{array}{c}\text { Duration of } \\
\text { Analgesia(min) }\end{array}$ & $121.5 \pm 20.2$ & $119.5 \pm 13.36$ & $124.5 \pm 17.08$ & 0.433 & 0.651 \\
\hline
\end{tabular}

Sensory blockade-The level of block in control group extended between T6 to L1. In the study group I, the block extended between T9 - T12. In the study group II, the block extended between T8 and T12. The median level of block was between T9 - T10 in all 3 groups. There was no statistical difference in the level of sensory blockade among the groups. There was no statistical difference in the onset time and duration of sensory and motor blockade among the groups. (Graph 1) (Table 5).
Graph 1. Range of level of sensory blockade among three groups

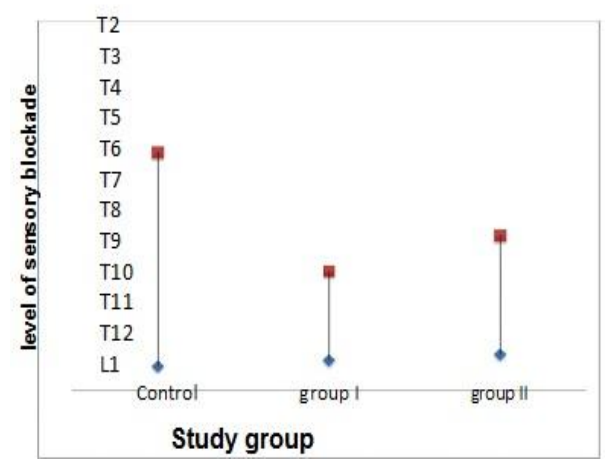


Graph 2: Percentage of bradycardia among three groups.

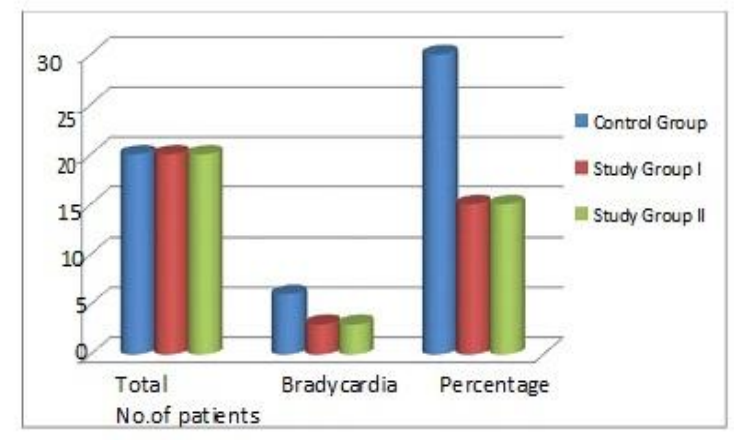

Graph 3: Percentage of hypotension am ong three groups

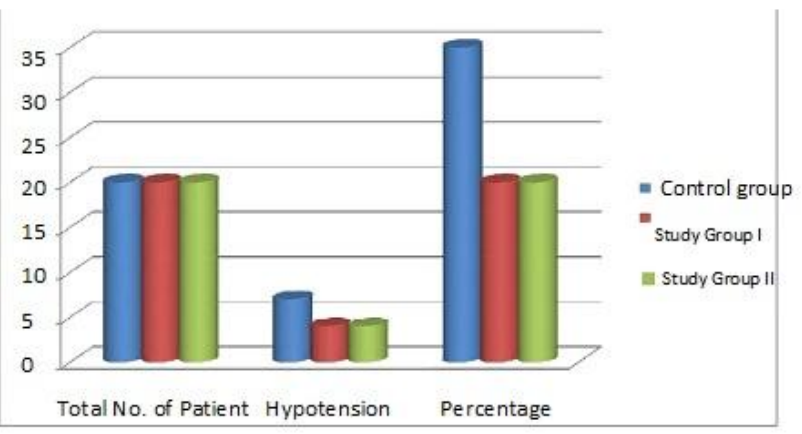

\section{DISCUSSION}

Maximum ASA III \& IV patients belong to geriatric age group. Cardiac reserve is reduced in elderly patients and this may become evident during perioperative period. Hypotension occurs more frequently and with greater severity during anaesthesia because of impaired autonomic function.

Distance between left and right spinal roots is only 10-15 millimetre in lumbar and lower thoracic level. Such a small distance might prevent from producing strictly unilateral block of spinal nerve roots. However, various clinical reports suggested that using small doses of either hypo or hyperbaric ${ }^{11,12,13}$ anesthetic solution injected at slow speed through directional needles in lateral decubitus ${ }^{3,14,15}$ position for 10-15 minutes results in preferential distribution of spinal anaesthesia. This provide intense surgical block on preferred side ${ }^{14,16}$ when small doses of bupivacaine is used ${ }^{3,11,17}$. Unilateral low dose spinal anaesthesia provides better outcome in high risk patients ${ }^{18}$

\section{UNILATERAL SPINAL ANAESTHESIA}

In this study the onset time for loss of pin prick sensation at $\mathrm{T} 10$ and in both the limbs was between 5 to 7 minutes. This was similar to the onset time of block with classical subarachnoid technique. Caseti A, Fanelli $\mathrm{G}$ et $\mathrm{al}^{3}$ found onset times in dependent limb to be more rapid when compared to non-dependent limb. In our study we were not able to demonstrate any obvious difference in onset times.

\section{SENSORY BLOCKADE}

Sensory blockade was assessed in the dependent as well as nondependent limb. Sensation was assessed using pin prick by a blinded observer. In our study sensory block had a wide variation in the upper level of block between the dependant and nondependent limb at 15 minutes. But with the passage of time this difference was narrowed or obliterated. In control group the sensory block extended between T6 - L1 with median being T9T10. In study group I the block extended between T9 - T12 with the median of T10. In study group II the block extended between T8 - T12 with the median of T10. This was not statistically significant. Four out of forty patients in the unilateral group (Study group I and II) had no sensory loss in the non dependent limbs. It was also not statistically significant.

A Casati, G. Fanelli et $\mathrm{al}^{3}$ in their study demonstrated a difference in maximum sensory block achieved between the 2 limbs. On the dependant limb the block extended between L1 to $\mathrm{T} 2$ with a mean of T10 and on the non dependent limb extended between T6 to L2 with a mean of T12.

Battista Borghi et $\mathrm{al}^{19}$ found that sensory block in dependent limb was T9 in unilateral block and T7 in bilateral block. In our study there was no statistically significant difference in sensory block between the 2 limbs with average sensory blocks in both limbs being T10. 


\section{MOTOR BLOCKADE}

Analysis of motor block was done using Modified Bromage Scale both in the dependent and nondependent limb exclusively.

Control group showed no statistically significant difference in motor blockade between the limbs. Establishment and regression of motor blockade as recorded at 15 mins and 60 mins also were matched between the two limbs.

Study group I showed a statistically significant difference in motor blockade between the two limbs at 15 mins. Significant motor blockade in dependant limb was 18/20 and in non dependent limb was 10/20. At 60 mins significant motor blockade in the dependent limb was 20/20 and in the non dependent limb was 12/20.

Study group II showed statistically significant motor block on dependent limb 19/20 versus the non dependent limb $7 / 20$ at 15 minutes. This reflects that onset time is faster and denser in the dependent limbs. At 60 mins the dependent limb had significant motor blockade of 20/20 while in the non dependent limb motor blockade was $11 / 20$. So as the time elapsed the differential blockade obtained between the two limbs seems to have reduced probably reflecting slow spread of local anaesthetics to the nondependent limb also on assumption of supine position.

Analysis of motor blockade in the 3 groups showed that unilateral spinal block and low dose spinal block induced lesser degree of motor blockade when compared to the classical subarachnoid block group. This difference was found to be statistically significant.

In the study group 1 and 2 the onset of motor blockade was faster and the degree of motor blockade was more in the dependant limb when compared to nondependent limb. This difference was also found to be statistically significant. Borghi et al $^{19}$ also demonstrated a difference in motor block between the dependant and nondependent limbs. They recorded a Bromage score of $0 / 1 / 2 / 3$ of $0 / 2 / 3 / 45$ in unilateral group in the dependent limb and Bromage score of $0 / 1 / 2 / 3$ of $0 / 3 / 11 / 36$ in the classical subarachnoid block.
In our study we recorded a Bromage scale on the operating limb with classical sub arachnoid block $0 / 1 / 2 / 3$ as $0 / 0 / 3 / 17$. There was no difference between the 2 limbs.

In group I on the dependent limb Bromage score were 2/0/7/11 and in non dependent limb 8/2/4/6. In group II the dependent limb had Bromage score of $1 / 0 / 7 / 12$ and in non dependent limb had score of $6 / 7 / 2 / 5$. These differences were statistically significant and they coincide with findings recorded in the study of Borghi et al.

\section{HAEMODYNAMIC STABILITY AND COMPLICATIONS}

In our study hemodynamic stability as evidenced by systolic blood pressure, diastolic blood pressure and mean arterial blood pressure was comparable between study group I and II. Four patients had hypotension of more than $30 \%$ from base line values that required treatment. Control group had higher incidence hypotension (in 7 patients) requiring treatment with vasopressors, and fluids (crystalloid/colloids).

Casati Fanelli et $\mathrm{al}^{3}$ reported a higher incidence of hypotension in classical group (22.4\%) than unilateral group $(5 \%)$. The change in systolic blood was $-28 \% \pm 16 \%$ in classical group and $-8 \%$ $\pm 11 \%$ in unilateral group. Heart rate variation in their study was $-19 \% \pm 10 \%$ in classical group and $-12 \% \pm 18 \%$ in unilateral group.

In our study classical group showed greater fall in heart rate and blood pressure than the unilateral group. Study group I and II had lesser incidence of hemodynamic problems. These differences were also found to be statistically significant. (Graph 2, Graph 3)

\section{CONCLUSION}

From this study we can conclude that, in high risk patients undergoing emergency unilateral lower limb surgeries:

Unilateral low dose subarachnoid block offers better hemodynamic stability during the intraoperative period.

The onset, quality and duration of block match those produced by classical subarachnoid block. 
It is possible to produce unilateral subarachnoid block by maintaining patients in lateral position for 10 minutes.

\section{Acknowledgement}

We are thankful to the Dean, Head of the department and Postgraduate students of Department of Anaesthesia for their kind support during this study.

\section{Conflict of interest -None \\ Funding --None}

\section{REFERENCES}

1. Fanelli G, Torri G, Bilateral Versus unilateral selective subarachnoid anesthesia; cardiovascular homeostasis. $\mathrm{Br} \mathrm{J}$ Anaesthesia.1996; 76; A242.

2. Imbelloni, Unilateral spinal anaesthesia with low $0.5 \%$ hyperbaric bupivacaine dose.Rev.Bras.Anaesth.Vol.54.sep 2004.

3. Casati A, Fenelli G, et al. Effects of speed of intrathecal injection on unilateral spinal block. Minerva Anesth.1999; 65; 5-10.

4. Esmaoglu A, Karaoglu S, Mizrak A, Boyaci A. Bilateral vs unilateral spinal anaesthesia for outpatient knee arthroscopies. Knee Surg Sports Traumatol Arthrosc. 2003; 12:155-158.

5. Sotig D, Greilich NB, White PF, Watcha MF, Tongier WK. Recovery profiles and costs of anesthesia for outpatient unilateral inguinal herniorrhaphy. Anesth Analg. 2000; 91:876- 881.

6. Casati A, Fanelli G, Aldegheri G, et al. Frequency of hypotension during conventional or asymmetric hyperbaric spinal block. Reg Anesth Pain Med. 1999; 24:214-219.

7. Fanelli G, Borghi B, Casati A, Bertini L, Montebugnoli M, Torri G. Unilateral bupivacaine spinal anesthesia for outpatient knee arthroscopy. Italian Study Group on Unilateral Spinal Anesthesia. Can J Anaesth. 2000; 47:746-751.
8. Liu SS, Ware PD, Allen HW, Neal JM, Pollock JE. Dose response characteristics of spinal bupivacaine in volunteers. Clinical implications for ambulatory anesthesia. Anesthesiology.1996; 85:729-736.

9. Chambers, WA Edstrim, HH, and Scott, DB , effect of baricity on spinal anaesthesia with bupivacaine Br.J. Anaesth, 53 $198153 ; 279$.

10. Whiteside JB, Burke and Wildsmith AW. Spinal anaesthesia with ropivacaine $5 \mathrm{mg}$ $\mathrm{ml}$ in glucose $10 \mathrm{mg} \mathrm{ml}$ or $50 \mathrm{mg} \mathrm{ml}$. Brt Jour Anesth 2001; 86(2) 241-244

11. Kuusniemi KS, Pihlajamaki KK and Pitkanen MT. A low dose of plain or hyperbaric. Bupivacaine for unilateral spinal anesthesia. Reg Anesth Pain Med 2004; 29 (1); 17-22.

12. Serpell MG, Gray W. Flow dynamics through spinal needles. Anesthsia 1997; 52:229-36.

13. Tecklenburg WE, Quest F, Nolte H and Meyer J. The effect of patient positioning on the spread of sensory blockade in hyperbaric and isobaric spinal anesthesia using bupivacaine. Reg Anaesth. 1990 ;13(7):163-7

14. Kristiina S, Kuusniemi MD, Kalevi K, Pihlajamaki and Mikko TP. A low dose of plain or hyperbaric bupivacaine for unilateral spinal anes Anasthesiol Intensivmed Notfallmed Schmerzther. 2002; 37(11); 654-659

15. Povey H M R, Jacobsen J, et al. Subarachnoid analgesia with hyperbaric $0.5 \%$ bupivacaine: effect of a $60 \mathrm{~min}$ period of sitting. Acta Anaesthesiol Scand 1989; 33; 295-7.

16. Frank A, Schuster $M$ and Biscoping J. Influence of positioning on the quality of unilateral spinal anesthesia.Reg Anesth Pain Med. 2000; 25 (6); 605 - 610.

17. Dobrydnjov I, Axelsson K, Thorn S-E, et al. Clonidine combined with small-dose bupivacaine during spinal anesthesia for inguinal herniorrhaphy: a randomized 
double-blinded study. Anesth Analg 2003;96:1496-503

18. Chohan U1, Afshan G, Hoda MQ, Mahmud S. Haemodynamic effects of unilateral spinal anesthesia in high risk patients. J Pak Med Assoc. 2002 Feb; 52(2):66-9.

19. Borghi B, Fanelli G, Cappelleri G, Casati A Borghi B, Cedrati V and Torri G. Low dose Hyperbaric bupivacaine for unilateral spinal anaesthesia. Can J Anaesth. 1998; 45(9):850-4. 